\title{
KOORDINASI ANTAR LEMBAGA DALAM PENANGANAN ORANG DENGAN GANGGUAN JIWA TERLANTAR DI KOTA SUKABUMI
}

\author{
Nandini Audina ${ }^{1}$, Ike Rachmawati ${ }^{2}$, \& Dian Purwanti ${ }^{3}$ \\ ${ }^{1}$ Universitas Muhammadiyah Sukabumi \\ Email: audinanandini@gmail.com \\ ${ }^{2}$ Universitas Muhammadiyah Sukabumi \\ Email: ike_rachmawatil@yahoo.com \\ ${ }^{3}$ Universitas Muhammadiyah Sukabumi \\ Email: purwantidian75@yahoo.com
}

\begin{abstract}
Abstrak
Penelitian ini berawal dari fenomena masih sering ditemuinya orang dengan gangguan jiwa terlantar yang berkeliaran di Kota Sukabumi. Penanganan orang dengan gangguan jiwa terlantar tidak ditangani oleh satu lembaga, oleh karena itu perlu adanya koordinasi antara Dinas Sosial, Dinas Kesehatan dan Satuan Polisi Pamong Praja. Penelitian ini bertujuan untuk menganalisis koordinasi antar lembaga dalam penanganan orang dengan gangguan jiwa terlantar di Kota Sukabumi dengan menggunakan teori koordinasi yang dikemukakan oleh Hasibuan yang terdiri dari empat dimensi, yaitu kesatuan tindakan, komunikasi, pembagian kerja, dan disiplin. Metode yang digunakan dalam penelitian ini adalah metede penelitian kualitatif. Hasil penelitian menemukan bahwa koordinasi dalam penanganan orang dengan gangguan jiwa di Kota Sukabumi masih belum maksimal karena belum adanya kesatuan tindakan antar lembaga, komunikasi yang dilakukan antar lembaga tidak intensif, dan pembagian kerja yang belum optimal. Oleh karena itu harus adanya kesatuan tindakan antar lembaga, rapat koordinasi dilaksanakan secara rutin, adanya pedoman dalam penanganan yang disepakati bersama, serta penyediaan anggaran yang cukup.
\end{abstract}

Kata Kunci: koordinasi, lembaga pemerintah, orang dengan gangguan jiwa.

\begin{abstract}
This study originated from the phenomenon that people with deranged mental disorders who roam the city of Sukabumi are still frequently encountered. The handling of people with mental disorders who are displaced is not handled by one institution, therefore there is a need for coordination between the Social Service, the Health Service and the Civil Service Police Unit. This study aims to analyze coordination between institutions in the handling of people with mental disorders who are displaced in Sukabumi City by using the coordination theory proposed by Hasibuan which consists of four dimensions, namely unity of action, communication, division of work, and discipline. The method used in this research is qualitative research metede. The results found that coordination in handling people with mental disorders in the City of Sukabumi was still not optimal because there was no unity of action between institutions, communication between agencies was not intensive, and the division of labor was not optimal. Therefore there must be unity of action between institutions, coordinating meetings are held routinely, there are guidelines in handling mutually agreed upon, as well as providing sufficient budget.
\end{abstract}

Keywords: coordination, government agencies, people with mental disorders. 


\section{A. PENDAHULUAN}

Menurut Undang-Undang Nomor 18 Tahun 2014 dinyatakan bahwa Orang Dengan Gangguan Jiwa yang selanjutnya disingkat ODGJ adalah orang yang mengalami gangguan dalam pikiran, perilaku, dan perasaan yang termanifestasi dalam bentuk sekumpulan gejala dan/atau perubahan perilaku yang bermakna, serta dapat menimbulkan penderitaan dan hambatan dalam menjalankan fungsi orang sebagai manusia.

Kota Sukabumi sendiri masih terdapat orang dengan gangguan jiwa yang terlantar atau menggelandang. Orang dengan gangguan jiwa yang menggelandang tersebut tidak semua penduduk asli Kota Sukabumi namun sebagian berasal dari daerah lain. Orang dengan gangguan jiwa tersebut di tangani oleh Dinas Sosial Kota Sukabumi, dan dalam penertibannya Dinas Sosial bekerja sama dengan Satuan Polisi pamong Praja (Satpol PP) Kota Sukabumi. Dalam penanganan orang dengan gangguan jiwa tersebut masih terdapat kendala karena di Kota Sukabumi sendiri tidak memiliki panti ataupun tempat rehabilliasi untuk menampung orang dengan gangguan jiwa terlantar.

Dalam Penanganan ODGJ sendiri sebenarnya tidak bisa hanya di tangani oleh satu instansi saja, harus adanya koordinasi antar lembaga agar dalam penanganannya berjalan secara maksimal. Dinas Sosial Harus berkoordinasi dengan Dinas Kesehatan dan Satuan Polisi Pamong Praja (Satpol PP). Upaya penanganan orang dengan gangguan jiwa terlantar berupa penertiban sebenarnya telah sering dilakukan oleh Dinas Sosial maupun satpolpp. Namun dalam pelaksanaannya belum optimal karena tidak adanya koordinasi antara Satpol PP dengan Dinas Sosial. Sehingga tidak adanya kejelasan siapa yang seharusnya bertanggung jawab dalam menangani orang dengan gangguan jiwa terlantar di Kota Sukabumi. Akibatnya terjadi saling lempar tanggung jawab ketika masyarakat melaporkan keberadaan orang dengan gangguan jiwa terlantar kepada Dinas Sosial maupun Satpolpp. Satpol PP menganggap hal tersebut adalah kewajiban Dinas Sosial begitu pula sebaliknya.

Menurut Dinas Sosial tidak adanya keseimbangan tugas dan tanggung jawab yang dibebankan kepada Dinas Sosial dan Dinas Kesehatan. Dimana Dinas Kesehatan hanya bertugas menangani orang dengan gangguan jiwa warga Kota Sukabumi saja, sementara Dinas Sosial harus menangani orang dengan gangguan jiwa terlantar yang tidak hanya warga Kota Sukabumi, tetapi juga dari luar Kota Sukabumi yang dikirim oleh daerah lain ke Kota Sukabumi. Tidak adanya sarana dan prasarana pendukung berupa rumah singgah atau panti orang dengan gangguan jiwa terlantar juga menjadi kendala bagi Dinas Sosial dalam upaya penanganan orang dengan gangguan jiwa terlantar di Kota Sukabumi. 
Penelitian ini bertujuan untuk menganalisis koordinasi antar lembaga dalam penanganan orang dengan gangguan jiwa terlantar di Kota Sukabumi dengan menggunakan teori koordinasi yang dikemukakan oleh Hasibuan yang terdiri dari empat dimensi, yaitu kesatuan tindakan, komunikasi, pembagian kerja, dan disiplin.

\section{B. KAJIAN PUSTAKA}

\section{Pegertian Koordiasi}

Menurut Hasibuan (2006), koordinasi adalah kegiatan mengarahkan, mengintegrasikan, dan mengkoordinasikan unsur-unsur manajemen (6M) dan pekerjaanpekerjaan para bawahan dalam mencapai tujuan organisasi.

Sedangkan Terrry dalam Hasibuan (2006), mengemukakan bahwa koordinasi adalah suatu usaha yang sinkron dan teratur unutk menyediakan jumlah dan waktu yang tepat, dan mengarahkan pelaksanaan untuk menghasilkan suatu tindakan yang seragam dan harmonis pada sasaran yang telah ditentukan.

Sedangkan menurut Brech dalam Hasibuan (2014), menyatakan bahwa koordinasi adalah mengimbangi dan mengarahkan tim dengan memberikan lokasi kegiatan pekerjaan yang cocok pada masing-masing dan menjaga agar kegiatan itu dilaksanakan dengan keselarasan yang semestinya diantara para anggota itu sendiri.

\section{Jenis-Jenis Koordinasi}

Secara teoritis Sugandha (1991), menyebutkan beberapa jenis koordinasi sesuai dengan lingkup dan arah jalurnya. Menurut lingkupnya, koordinasi terdiri dari koordinasi intern yaitu antar pejabat antar unit di dalam suatu organssasi, dan koordiansi ektern yaitu Koordinasi antar pejabat dari berbagai organisasi atau antar kelompk organisasi. Sementara menurut arahnya, koordiasi terdiri dari: 1) Koordinasi horizontal yaitu koordinasi antar pejabat atau antar unit yang mempunyai tingkat hierarki yang sama dalam suatu organisasi, dan antar pejabat dari organisasi-organisasi yang sederajat atau antar organisasi yang setingkat, 2) Koordinasi vertical yaitu koordinasi antar pejabat-pejabat dan unit-unit tingkat bawah oleh pejabat atasannya atau unit tingkat atasnya langsung, 3) Koordinasis diagonal yaitu koordinasi antar pejabat atau uni yang berbeda fungsi dan berbeda tingkatan hierarkinya, dan 4) Koordinasi Fungsional adalah koordinasi antar pejabat atau unit atau antar organisasi yang didasarkan atas kesamaan fungsi. 


\section{Faktor-Faktor Yang Mempengarui Koordinasi}

Menurut Hasibuan (2006), faktor-faktor yang mempengaruhi koordinasi adalah sebagai berikut:

a. Kesatuan Tindakan

Pada hakekatnya koordinasi memerlukan kesadaran setiap anggota organisasi atau satuan organisasi untuk saling menyesuaikan diri atau tugasnya dengan anggota atau satuan organisasi lainnya agar anggota atau satuan organisasi tersebut tidak berjalan sendiri-sendiri. Oleh sebab itu konsep kesatuan tindakan adalah inti dari pada koordinasi. Kesatuan dari pada usaha, berarti bahwa pemimpin harus mengatur sedemikian rupa usaha-usaha dari pada tiap kegiatan individu sehingga terdapat adanya keserasian di dalam mencapai hasil. Kesatuan tindakan ini adalah merupakan suatu kewajiban dari pimpinan untuk memperoleh suatu koordinasi yang baik dengan mengatur jadwal waktu dimaksudkan bahwa kesatuan usaha itu dapat berjalan sesuai dengan waktu yang telah direncanakan.

b. Komunikasi

Komunikasi tidak dapat dipisahkan dari koordinasi, karena komunikasi, sejumlah unit dalam organisasi akan dapat dikoordinasikan berdasarkan rentang dimana sebagian besar ditentukan oleh adanya komunikasi. Komunikasi merupakan salah satu dari sekian banyak kebutuhan manusia dalam menjalani hidup dan kehidupannya. "Perkataan komunikasi berasal dari perkataan communicare, yaitu yang dalam bahasa latin mempunyai arti berpartisipasi ataupun memberitahukan" Dalam organisasi komunikasi sangat penting karena dengan komunikasi partisipasi anggota akan semakin tinggi dan pimpinan memberitahukan tugas kepada karyawan harus dengan komunikasi. Dengan demikian komunikasi merupakan hubungan antara komunikator dengan komunikan dimana keduanya mempunyai peranan dalam menciptakan komunikasi.

c. Pembagian Kerja

Pembagian kerja pekerjaan menyebabkan kenaikan efektifitas secara dramatis, karena tidak seorangpun secara fisik mampu melaksanakan keseluruhan aktifitas dalam tugas-tugas yang paling rumit dan tidak seorangpun juga memiliki semua keterampilan yang diperlukan untuk melaksanakan berbagai tugas. Oleh karena itu perlu diadakan pemilahan bagian-bagian tugas dan membagi baginya kepada sejumlah orang. Pembagian pekerjaan yang dispesialisasikan seperti itu 
memungkinkan orang mempelajari keterampilan dan menjadi ahli pada fungsi pekerjaan tertentu.

d. Disiplin

Pada setiap organisasi yang kompleks, setiap bagian harus bekerja secara terkoordinasi, agar masing-masing dapat menghasilkan hasil yang diharapkan. Koordinasi adalah usaha penyesuaian bagian-bagian yang berbeda-beda agar kegiatan dari pada bagian-bagian itu selesai pada waktunya, sehingga masingmasing dapat memberikan sumbangan usahanya secara maksimal agar diperoleh hasil secara keseluruhan, untuk itu diperlukan disiplin. Disiplin adalah suatu alat yang digunakan para manajer untuk berkomunikasi dengan karyawan agar mereka bersedia untuk mengubah suatu perilaku serta sebagai suatu upaya untuk meningkatkan kesadaran dan kesediaan seseorang mentaati semua peraturan organisasi dan norma-norma sosial yang berlaku”. Jadi jelasnya bahwa disiplin menyangkut pada suatu sikap dan tingkah laku, apakah itu perorangan atau kelompok yang untuk tunduk dan patuh terhadap peraturan suatu organisasi.

\section{Kesehatan Jiwa}

Notosoedirdjo dalam Eko Prabowo (2014), mendefinisikan gangguan jiwa sebagai sindrom atau pola psikologis atau pola perilaku yang penting secara klinis, yang terjadi pada individu dan sindrom itu dihubungkan dengan adanya distress (misalnya, gejala nyeri, menyakitkan) atau disabilitas (ketidakmampuan pada salah satu bagian atau beberapa fungsi penting) atau disertai peningkatan resiko secara bermagna untuk mati, sakit, ketidakmampuan, atau kehilangan kebebasan.

Sementara menurut Undang-Undang No. 18 tahun 2014, Orang Dengan Gangguan Jiwa yang selanjutnya disingkat ODGJ adalah orang yang mengalami gangguan dalam pikiran, perilaku, dan perasaan yang termanifestasi dalam bentuk sekumpulan gejala dan/atau perubahan perilaku yang bermakna, serta dapat menimbulkan penderitaan dan hambatan dalam menjalankan fungsi orang sebagai manusia. Sedangkan menurut Peraturan Daerah Provinsi Jawa Barat No. 5 Tahun 2018, Psikotik Jalanan atau Gelandangan Psikotik adalah orang dengan gangguan jiwa yang menggelandang. 


\section{METODE PENELITIAN}

Metode yang digunakan dalam penelitian ini adalah metode penelitian deskriptif kualitatif. Data yang diperoleh menggunakan observasi, wawancara dan dokumentasi. Sedangkan teknik pengambilan data adalah purposive sampling. Informan dalam penelitian ini antar lain: Kepala Bagian Rehabilitasi Sosial Dinas Sosial, Kepala Seksi Rehabilitasi Sosial, Satuan Polisi Pamong Praja dan Dinas Kesehatan. Prosedur pengujian keabsahan data dilakukan dengan teknik triangulasi. Proses analisis data dalam penelitian ini menggunakan model analisis data yang dikemukakan oleh Miles and Huberman (Sugiyono, 2016).

\section{HASIL DAN PEMBAHASAN}

\section{Dimensi Kesatuan Tindakan}

Konsep kesatuan tindakan adalah merupakan inti dari koordinasi. Kesatuan dari pada usaha, berarti bahwa harus mengatur sedemikian rupa usaha-usaha tiap kegiatan individu sehingga terdapat adanya keserasian di dalam mencapai hasil. Mengingat banyaknya lembaga yang terlibat dalam penanganan orang dengan gangguan jiwa terlantar maka haruslah ada kesatuan tindakan yang disepakati bersama agar hasil yang diinginkan dapat tercapai.

Kesatuan tindakan dalam koordinasi ini artinya dalam penanganannya lembaga terkait harus sepakat bahwa orang dengan gangguan jiwa terlantar akan ditangani dengan tindakan yang sama. Tindakan dalam tindakan penanganan orang dengan gangguan jiwa terlantar yang dilakukan dalam penanganan orang dengan jiwa terlantar dilakukan oleh Dinas Sosial adalah dikirim ke tempat rehabilitasi Sosial yang berada di Kabupaten Sukabumi atau ke tempat rehabilitasi yang berada di Kota lain karena di Kota Sukabumi sendiri tidak memiliki panti rehabilitasi. Untuk Satpol PP tindakannya adalah menertibkan dijalan dan mengatakan orang dengan gangguan jiwa terlantar sendiri merupakan program Dinas Sosial, begitupun yang disampaikan oleh Dinas Kesehatan.

Satpol PP mengatakan bahwa di Dinas Sosial sendiri sudah tim ada tim Khusus penanganan orang dengan gangguan jiwa terlantar sehingga berharap Dinas Sosial tidak harus selalu berkoordinasi dengan Satpolpp. Namun terkadang adanya tindakan saling buang orang dengan gangguan jiwa terlantar antar kota dan daerah yang dilakukan oleh Satpol PP dalam penanganannya. Hal tersebut menjadikan adanya perbedaan penanganan, Dinas Sosial mengupayakan orang dengan gangguan jiwa terlantar dikirim ke tempat rehabilitasi, tetapi disisi lain masih ada tindakan pembuangan orang dengan gangguan jiwa. Hal ini berarti 
belum adanya kesatuan tindakan antar lembaga dalam penanganan orang dengan gangguan jiwa terlantar di Kota Sukabumi.

Menurut Hasibuan (2006), koordinasi memerlukan kesadaran setiap anggota organisasi atau satuan organisasi untuk saling menyesuaikan diri atau tugasnya dengan anggota atau satuan organisasi lainnya agar anggota atau satuan organisasi tersebut tidak berjalan sendiri-sendiri.

Tidak adanya kesatuan tindakan yang dilakukan antar lembaga terkait membuat penanganan orang dengan gangguan jiwa terlantar akan tidak akan maksimal. Bila setiap lembaga yang terlibat melakukan tindakan yang berbeda terkait penanganan orang dengan gangguan jiwa terlantar maka masalah tersebut tidak akan terselesaikan. Hal itu juga berarti bahwa lembaga yang terlibat tidak memiliki koordinasi yang baik. Bila peneliti kaitkan dengan penelitian terdahulu harus adanya nilai bersama dari pihak yang berkoordinasi dalam penanganan orang dengan gangguan jiwa terlantar ditandai dengan adanya kebersamaan yang terbangun dengan baik dan nilai yang dijunjung bersama oleh masing-masing pihak.

\section{Dimensi Komunikasi}

Komunikasi merupakan variabel penting yang mempengaruhi koordinasi. komunikasi sangat menentukan keberhasilan dalam melaksanakan koordinasi, Karena dengan komunikasi seseorang dapat memberikan atau menerima informasi sehingga pelaksanaan koordinasi dapat berjalan dengan baik.

Dalam melaksanakan tugas penanganan orang dengan gangguan jiwa terlantar, lembaga atau instansi diharapkan melakukan komunikasi dengan sesama lembaga yang berkaitan agar tugas dapat berjalan sesuai dengan peraturan yang telah ditetapkan. Komunikasi yang dimaksud dalam penelitian ini adalah bagaimana lembaga yang terlibat dapat saling memberi informasi tentang penanganan orang dengan gangguan jiwa terlantar juga kendala-kendala yang dihadapi masing-masing.

komunikasi belum dilakukan secara optimal antar lembaga yang terlibat baik secara formal maupun informal, karena rapat koordinasi antar lembaga yang terlibat tidak rutin dilaksanakan dan hanya dilakukan satu kali dalam satu tahun, selain itu penyebaran informasi antar lembaga hanya sebatas memberitahu keberadaan orang dengan gangguan jiwa terlantar saja. Padahal komunikasi sangat penting dalam sebuah koordinasi karena dengan adanya komunikasi yang baik antar lembaga dapat saling memberi informasi terkait masalah orang dengan gangguan jiwa terlantar di Kota Sukabumi, kemudian mengevaluasi 
sudah sejauh mana penanganan orang dengan gangguan jiwa terlantar dilakukan serta kendala-kendala yang dihadapi antar lembaga dalam penanganan orang dengan gangguan jiwa terlantar.

Komunikasi yang intensif akan mempengaruhi dalam tindakan-tindakan yang dilakukan dalam penanganan orang dengan gangguan jiwa terlantar. Tidak akan ada kesatuan tindakan antar lembaga yang terlibat bila komunikasi yang dilakukan saja tidak optimal. Kesatuan tindakan muncul karena antar lembaga terkait melakukan komunikasi yang intesif sehingga adanya kesepakatan bersama bagaimana seharusnya penanganan orang dengan gangguan jiwa terlantar di Kota Sukabumi. Selain itu, dengan adanya komunikasi yang baik antar lembaga akan adanya kesepakatan dalam hal pembagian tugas sesuai dengan kapasitasnya masing-masing, sehingga tidak adanya saling lempar tanggung jawab.

\section{Dimensi Pembagian Kerja}

Pembagian kerja dalam pekerjaan menyebabkan kenaikan efektifitas secara dramatis, karena tidak seorangpun secara fisik mampu melaksanakan keseluruhan aktifitas dalam tugas-tugas yang paling rumit dan tidak seorangpun juga memiliki semua keterampilan yang diperlukan untuk melaksanakan berbagai tugas. Oleh karena itu perlu diadakan pemilahan bagian-bagian tugas dan membagi baginya kepada sejumlah orang. Pembagian pekerjaan yang dispesialisasikan seperti itu memungkinkan orang mempelajari keterampilan dan menjadi ahli pada fungsi pekerjaan tertentu. Karena dalam penanganan orang dengan gangguan jiwa terlantar melibatkan beberapa lembaga maka harus adanya pembagian tugas yang sesuai dengan kapasitasnya masing-masing sehingga dalam pelaksanaannya dapat berjalan dengan baik.

Pembagian kerja belum optimal karena masih adanya saling lempar tugas dalam penanganan orang dengan gangguan jiwa terlantar, hal tersebut menyebabkan tidak ada kejelasan siapa sebenarnya yang bertanggung jawab terkait masalah rehabilitasi, apakah orang dengan gangguan jiwa terlantar disembuhkan oleh Dinas Kesehatan atau dikirim langsung ke tempat panti sosial oleh Dinas Sosial. Namun dapat dilihat bahwa Dinas sosial bertanggung jawab atas pengupayaan panti sosial atau rehabilitasi sosial, satpolpp membantu dalam hal penertiban dan Dinas Kesehatan hanya memeriksa kesehatan orang dengan gangguan jiwa terlantar.

Adanya saling lempar tanggung jawab dalam penanganan orang dengan gangguan jiwa terlantar masih berkaitan dengan dimensi komunikasi yang kurang intensif, sehingga 
tidak adanya kesepakatan dalam pembagian tugas antar lembaga yang terlibat. Selain itu tidak adanya pedoman bersama dalam penanganan orang dengan gangguan jiwa terlantar di Kota Sukabumi yang menjelaskan secara rinci mengenai tujuan, sasaran, ataupun indikator kegiatan yang harus dilakukan oleh masing-masing lembaga sesuai dengan kapasitasnya masing-masing, serta untuk melihat sejauh mana keberhasilan lembaga terkait dalam menangani orang dengan gangguan jiwa terlantar di Kota Sukbumi. Seperti menurut Hasibuan (2006) pembagian kerja pekerjaan menyebabkan kenaikan efektifitas secara dramatis, karena tidak seorangpun secara fisik mampu melaksanakan keseluruhan aktifitas dalam tugas-tugas yang paling rumit dan tidak seorangpun juga memiliki semua keterampilan yang diperlukan untuk melaksanakan berbagai tugas.

\section{Dimensi Disiplin}

Disiplin dalam penanganan orang dengan gangguan jiwa terlantar berarti bahwa lembaga-lembaga terkait dapat melaksanakan tugasnya sesuai dengan peraturan dan pedoman yang ada. lembaga yang terlibat melakukan tugasnya sesuai dengan tupoksinya masing-masing, seperti Dinas Sosial dalam hal rehabilitasi sosial, Satpol PP dalam menertibkan dan ketentraman umum yaitu dengan melakukan penjaringan orang dengan gangguan jiwa terlantar, dan Dinas Kesehatan dalam pelayanan kesehatan bagi orang dengan gangguan jiwa.

Namun untuk kedisiplinan yang berkaitannya dengan koordinasi antar lembaga dalam penanganan orang dengan gangguan jiwa terlantar masih belum optimal, karena seperti belum adanya kesatuan tindakan antar lembaga yang terlibat, komunikasi yang dilakukan antar lembaga tidak intensif juga masih adanya saling lempar tanggung jawab penanganan. Hal tersebut menyebabkan dalam penanganan orang dengan gangguan jiwa terlantar tidak maksimal, selain itu karena tidak tersedianya panti rehabilitai menyebabkan masih seringnya ditemukan orang dengan gangguan jiwa terlantar di Kota Sukabumi. Kemudian hal lain yang terjadi yaitu masih sering terjadinya pembuangan orang dengan gangguan jiwa yang dilakukan antar daerah.

Hasibuan (2006) mengatakan bahwa, pada setiap organisasi yang kompleks, setiap bagian harus bekerja secara terkoordinasi, agar masing-masing dapat menghasilkan hasil yang diharapkan. Koordinasi adalah usaha penyesuaian bagian-bagian yang berbeda-beda agar kegiatan dari pada bagian-bagian itu selesai pada waktunya, sehingga masing-masing 


\section{ARTIKEL}

dapat memberikan sumbangan usahanya secara maksimal agar diperoleh hasil secara keseluruhan, untuk itu diperlukan disiplin.

\section{E. KESIMPULAN}

Berdasarkan hasil penelitian dapat disimpulkan bahwa belum adanya kesatuan tindakan antar lembaga yang terlibat dalam penanganan ODGJ terlantar di Kota Sukabumi, hal ini karena tidak adanya kesepakatan bahwa orang dengan gangguan jiwa terlantar akan ditangani dengan tindakan yang sama. Dinas Sosial menangani orang dengan gangguan jiwa terlantar dengan mengirim ke panti rehabilitasi, sedangkan masih ada tindakan pembuangan orang dengan gangguan jiwa yang dilakukan Satpol PP. Komunikasi yang dilakukan belum juga optimal karena jarang ada penyebaran dan pertukaran informasi, selain itu rapat koordinasi penanganan orang dengan gangguan jiwa terlantar antar lembaga yang terlibat sangat jarang dilakukan dan hanya dilakukan satu kali dalam satu tahun. Pembagian kerja sudah dilakukan sesuai kapasitasnya masing-masing namun masih adanya saling lempar tanggung jawab karena adanya ketidak jelasan kemana orang dengan gangguan jiwa terlantar akan direhabilitasi. Selain itu belum adanya pedoman yang bersifat formal yang disepakati bersama antar lemabaga yang terlibat dalam penanganan orang dengan gangguan jiwa terlantar. Kedisiplinan dalam melaksanakan tugas dalam penanganan orang dengan gangguan jiwa terlantar juga masih belum optimal.

\section{DAFTAR PUSTAKA}

Baihaqi. (2007). Psikiatri: Konsep Dasar dan Gangguan Gangguan. Bandung: Refika Aditama,

Hasibuan, M. S. P. (2006). Manajemen Dasar, Pengertian dan Masalah. Jakarta: Bumi Aksara.

Hasibuan, M. S. P. (2014). Manajemen Sumber Daya Manusia. Jakarta: Bumi Aksara

Keliat, B. A. (2006). Proses Keperawatan Kesehatan Psikiatri. Jakarta: Buku Kedokteran EGC

Ndraha, T. (2003). Kybernologi (Ilmu Pemerintahan Baru). Jakarta: Rineka Cipta.

Prabowo, E. (2014). Buku Ajar Keperawatan Jiwa. Yogyakarta: Nuha Medika.

Prabowo, E. (2014). Konsep dan Aplikasi Asuhan Keperwatan Jiwa. Yogyakarta: Nuha Medika.

Simon, H. A. (2007). Perilaku Administrasi. Jakarta: Bumi Aksara.

Sugandha, D. (1991). Koordinasi Alat Pemersatu Gerak Administarasi. Jakarta: Intermedia. Sugiyono. (2016). Metode Penelitian Kuantitatif Kualitatif dan R\&D. Bandung: Alfabeta.

Tomb, D. A. 2004. Psikiatri. Jakarta: Buku Kedokteran EGC.

Tunggal, A. W. (2002). Manajemen Suatu Pengantar. Jakarta: Rineka Cipta.

Yulianti, D. (2007). Kesehatan Jiwa dan Psikiatri. Jakarta: Buku Kedokteran EGC. 


\section{ARTIKEL}

Veithzal, R. (2005). Manajemen Sumber Daya Manusia. Jakarta: Raja Grafindo Persada.

Rachmawati, Ike dkk. 2018. Pedoman Penulisan Ristik dan Skriips Edisi V Tahun 2018. Sukabumi: Administrasi Public UMMI.

Peraturan Daerah Provinsi Jawa Barat Nomor 5 Tahun 2018 Tentang Penyelenggaraan Kesehatan Jiwa.

Undang-Undang Nomor 18 Tahun 2014 Tentang Kesehatan Jiwa. 